\title{
Radyofrekans ablasyon sonrası gelişen iki nadir komplikasyon
}

\author{
Two rare complications after radiofrequency ablation
}

\author{
A. Emre YILDIRIM ${ }^{1}$, Reskan ALTUN ${ }^{1}$, Demet FIRAT KAYA², Serkan ÖCAL ${ }^{1}$, Enver AKBAŞ ${ }^{1}$, Murat KORKMAZ ${ }^{1}$, \\ Haldun ŞELÇUK ${ }^{1}$, Uğur YILMAZ ${ }^{1}$ \\ Başkent Üniversitesi Tıp Fakültesi, ${ }^{1}$ Gastroenteroloji Bilim Dalı, ${ }^{2} I_{c ̧}$ Hastalıkları Anabilim Dalı, Ankara
}

Radyofrekans ablasyon uygulama kolaylığı, güvenilirliği ve başarılı sonuçlan nedeni ile primer karaciğer tümörlerinin tedavisinde kullanılmaktadır. Radyofrekans ablasyon karaciğer transplantasyonu öncesi köprü tedavisi olarak da kullanılmaktadır. Burada radyofrekans ablasyonun nadir görülen iki komplikasyonunu bildiriyoruz.

Anahtar kelimeler: Radyofrekans ablasyon, HCC, plevral efüzyon

\section{GİRIŞ}

Her yıl 626000 yeni vakaya hepatosellüler kanser (HCC) tanısı konmaktadır. Dünya genelinde 5. en sık görülen ve 3. en sık ölüm nedeni olan kanser türüdür (1). Rezeksiyon veya karaciğer transplantasyonunun mümkün olmadığı durumlarda lokal ablatif tedaviler uygulanabilir. Son ylllarda HCC tedavisinde radyofrekans ablasyon (RFA) kullanımı giderek artarak, perkütan alkol enjeksiyonunun (PAI) yerini almıştır. Daha büyük çaplı tümörlerdeki etkinliği, işlem sayısının azlığı ve daha az komplikasyon oranının yanında survi avantajı nedeni ile PAI'ye tercih edilmektedir (3). Burada RFA sonrası nadir görülen iki komplikasyonu bildiriyoruz.

\section{OLGU SUNUMU}

\section{VAKA I}

Hepatit C enfeksiyonuna bağlı kronik karaciğer hastalığı nedeniyle takip edilen 54 yaşındaki kadın hasta kontrol tetkiklerinde alfa feto protein yüksekliği ve abdomen tomografisinde karaciğerde 3 adet, en büyüğü 22 mm çapında olan HCC ile uyumlu lezyon izlenmesi üzerine hastaneye yatırıldı. Fizik muayenesinde orta derecede asit saptand. Kadavra listesinde nakil bekleyen hastaya RFA yapılması planlandı. İşlem sonrasında hastanın sağ üst kadranında orta aksiller hat ile ksefoid arasında kalan alanda arkus kostarum boyunca yaklaşı $5 \mathrm{~cm}$ eninde şişlik ve ağrı gelişmeye başladı. Tam kan takiplerinde hemoglobin değerinde belirgin düşme olmadı. Yapılan acil abdomen ultrasonografisinde (USG) kanama ile uyumlu görünüm izlenmedi. Hastanın ağrısı geriledi ancak takiplerinde şişlik gerilemedi. Yüzeyel doku USG'sinde peritoneal sıvının RFA traktı boyunca cilt altına sızdığı görüldü. Batında yaygın asit-
Radiofrequency ablation has become widely accepted as an approach against primary liver tumors because of its ease, safety of use and high level of effectiveness. radiofrequency ablation has also been performed as bridge therapy for hepatocellular carcinoma prior to liver transplantation. Herein, we report two rare complications of radiofrequency ablation.

Key words: Radiofrequency ablation, hepatocellular carcinoma, pleural effusion

ten dolayı artan peritoneal basınç sonrası peritoneal sıvının bu trakttan geçerek cilt altında toplandığı düşünüldü. İntraperitoneal basıncı azaltmak amacı ile peritoneal boşluğa kateter takılmasına karar verildi. Aralıklı kateterden sıvı boşaltılarak takip edildi. Cilt altı sıvının tamamen kaybolduğu gözlendi. Diüretik tedavisi düzenlenen hasta taburcu edildi. Bir ay sonra kontrole gelen hastanın USG'sinde cilt altında sıvı izlenmedi.

\section{VAKA II}

Hepatit C enfeksiyonuna bağlı karaciğer sirozu tanısıyla takip edilen ve karaciğer transplantasyon listesinde olan 64 yaşında erkek hasta, nefes darlığı ve karın şişliğinde artma nedeniyle başvurdu. Fizik muayenesinde karın distandü görünümde idi. Perküsyonda karında açıklığı yukarı bakan matite ve pretibial ödem saptandı. Akciğer grafisinde her iki kostofrenik sinüs açı idi, parankimde patoloji saptanmadi. Abdomen ultrasonografisinde masif asit tespit edildi. Laboratuar incelemesinde total bilirubin 4,3 mg/ dl, INR 2,2, albumin 2,3 g/dl idi. Hastanın MELD skoru 20 olarak hesaplandı. Örnekleyici parasentez yapıldı. Serum-asit albumin gradienti 1,5 g/ dl idi. Hücre sayımında 100 lökosit/ $\mathrm{mm}^{3}$ sayıldı. Asit sitolojisinde patoloji saptanmadi. Portal hipertansiyona sekonder asit olarak düşünüldü. Bir ay gibi kısa bir sürede asit toplanması nedeni ile olası malignite ve akut portal ven trombüsü ayırıcı tanısı için yapılan abdomen tomografisinde karaciğer sağ lob anterior superior segmentte yaklaşı $10 \mathrm{~mm}$ çapında HCC ile uyumlu görünümde lezyon saptandı (Resim 1). Lezyon biyopsisi HCC ile uyumlu gelen hastaya perkütan RFA yapıldı. İslemden yaklaşık 20 saat sonra hastada nefes darlığı başladı. Arteriyel kan gazı incelemesinde hipoksi izlendi. Akciğer gra- 


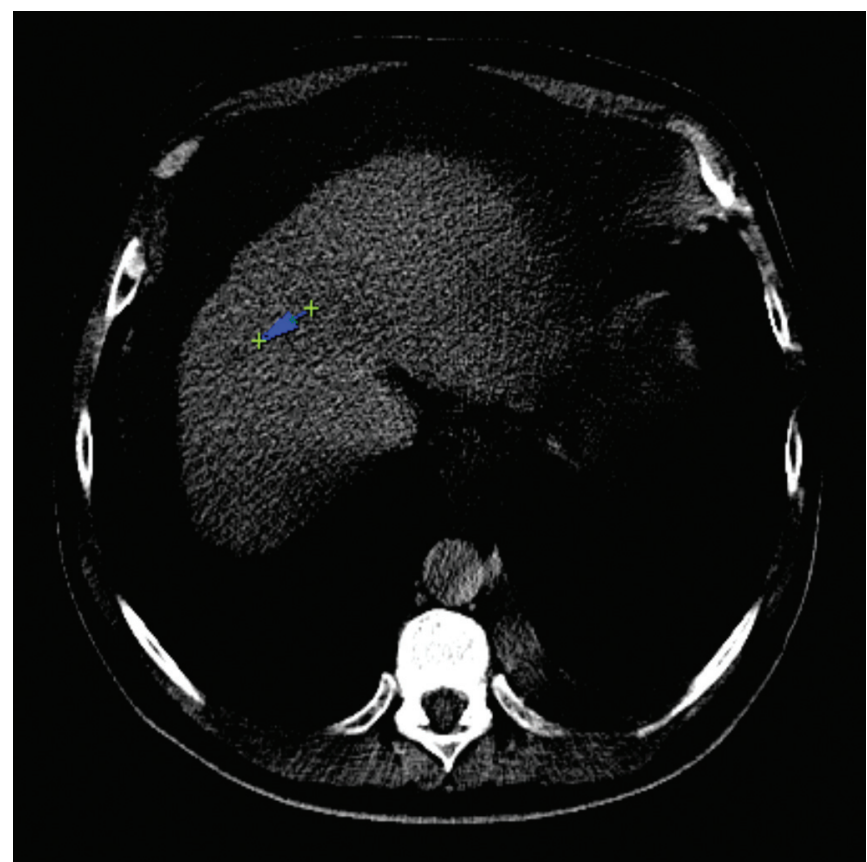

Resim 1. Segment 7'deki HCC

fisinde sağ akciğer alt lobda plevral efüzyon ve interlober fissurde belirginleşme görüldü (Resim 2). Hastanın nefes darlığının artması üzerine torasentez yapıldı. Plevral sıvı hemorajik vasıfta idi. Yaklaşık $1500 \mathrm{ml}$ sıvı boşaltıldıktan sonra nefes darlığı şikâyeti geriledi. Oksijen satürasyonu yükseldi. Ertesi gün çekilen akciğer grafisinde plevral efüzyonun ve interlober fissurdeki sıvı görünümünün tamamen kaybolduğu görüldü (Resim 3). Kliniği düzelen hasta diüretik tedavisi düzenlenerek taburcu edildi.

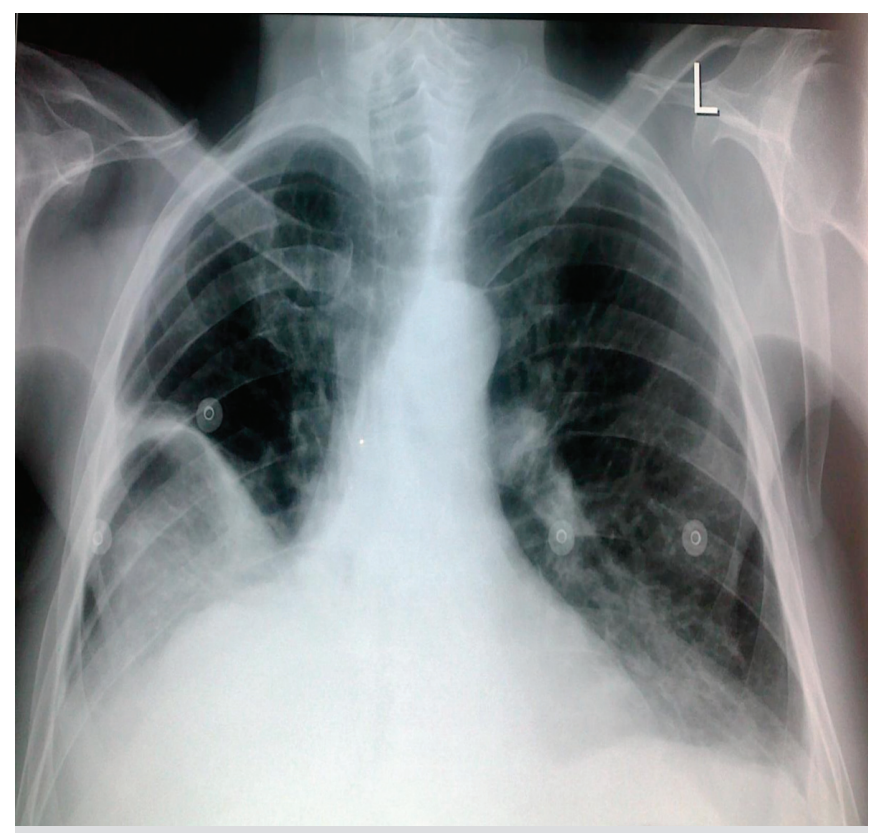

Resim 2. RFA sonrası plevral efüzyon ve fissür içerisinde sıvı

\section{TARTISMA}

Radyofrekans ablasyon, rezeksiyon veya karaciğer transplantasyonu yapılamayan HCC'li hastaların tedavisinde güvenilir ve etkin bir yöntemdir. Farklı komplikasyonları olmasına rağmen nadir görülür. Işlemin USG eşliğinde perkütan olarak yapılması, özellikle karaciğer segment 7-8 gibi ulaşılması zor lokalizasyonlardaki lezyonlarda, komplikasyon oranını arttırmaktadır. Livraghi ve arkadaşlarının serisinde mortalite \%0,3; kolon perforasyonu, tümör rüptürü sonucu hemoraji, peritonit ve septik şok gibi major komplikasyonlar \%2,2; cilt yanığı gibi minor komplikasyonlar da \%0,2 oranında bildirilmiştir (4). Izumi ve arkadaşlarının 133 hastalık serisinde ise hemotoraks \%0,3 ve pnömotoraks \%0,1 oranında bildirilmiştir (5). Kore'de yapılan çok merkezli bir başka çalışmada peritoneal hemoraji \%0,4 ve pnömotoraks \%0,2 hastada görülmüştür (6). Ülkemizde ise 29 hastanın incelendiği çalışmada, hastaların sadece birinde $(\% 3,4)$ plevral efüzyon ve sonrasinda gelişen ampiyem bildirilmiştir (7).

Cilt altına sızan periton sıvısının birikmesi sonucu ortaya çıkan kitle literatürde ilk defa bildirilen bir komplikasyondur. $\mathrm{Bu}$ komplikasyonun ortaya çıkmaması için masif asiti olan hastalarda RFA öncesi boşaltıcı parasentez ile karın içi basıncın azaltılması veya RFA sonrası ablasyon iğnesi çekilirken traktın daha agresif yakılmasının yararlı olacağı kanısındayız.

Diğer vakamızda ise segment 7'de bulunan lezyona yapılan RFA esnasında muhtemel plevra ponksiyonu sonucu periton sıvıs1nın plevral boşluğa geçerek efüzyona neden olduğunu düşünmekteyiz. İşlem sonrası ortaya çıkan nefes darlığı şikâyetinin olası plevral efüzyonun habercisi olabileceği, ampiyem olmadan yapılacak erken müdahalenin önemli olduğu kanısındayız.

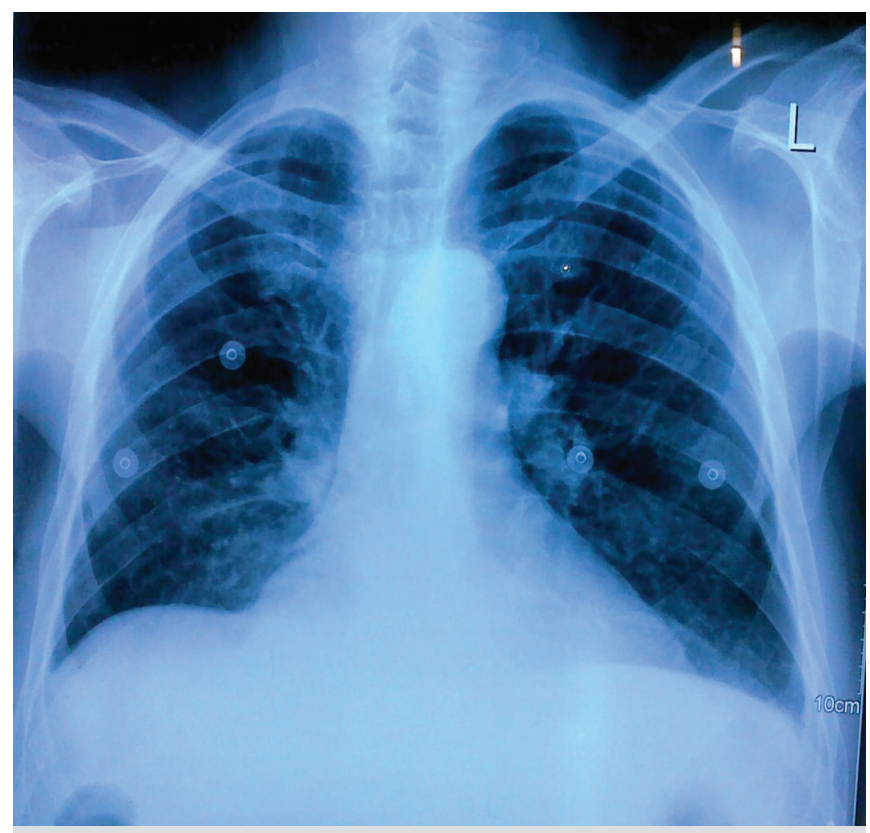

Resim 3. Torasentez sonrası efüzyonun kaybolması 


\section{KAYNAKLAR}

1. Ferlay J, Bray F, Pisani P, Parkin DM. GLOBOCAN 2002: Cancer Incidence, Mortality and Prevalence Worldwide. Lyon 2004; IARC CancerBase No. 5. version 2,0. Lyon: IARC Press.

2. Lin SM, Lin CJ, Lin CC, et al. Randomised controlled trial comparing percutaneous radiofrequency thermal ablation, percutaneous ethanol injection, and percutaneous acetic acid injection to treat hepatocellular carcinoma of $3 \mathrm{~cm}$ or less. Gut 2005; 54:1151-6.

3. Germani G, Pleguezuelo M, Gurusamy K, et al. Clinical outcomes of radiofrequency ablation, percutaneous alcohol and acetic acid injection for hepatocellular carcinoma: a meta-analysis. J Hepatol 2010; 52: 380-8.
4. Livraghi T, Solbiati L, Meloni MF, et al. Treatment of focal liver tumors with percutaneous complications encountered in a multicenter study. Radiology 2003; 226:441-51.

5. Izumi N. Recent advances of radiofrequency ablation for early hepatocellular carcinoma. J Gastroenterol Hepatol 2011; 26 (Suppl 1): 115-22.

6. Rhim H, Yoon KH, Lee JM et al. Major complications after radio-frequency thermal ablation of hepatic tumors: a spectrum of imaging findings. Radiographics 2003; 23: 123-34.

7. Geyik S, Akhan O, Abbasoğlu O, et al. Radiofrequency ablation of unresectable hepatic tumors. Diagn Interv Radiol 2006; 12: 195-200. 